\title{
IMPACT OF COVID19 ON ACCOUNTING PROFESSION FROM THE PERSPECTIVE OF A SAMPLE OF HEAD OF ACCOUNTING DEPARTMENTS WITHIN KUWAITI MANUFACTURING SECTOR
}

\author{
Dr. Bader Lafi Shallal Almutairi \\ PHD of Accounting ,Bader.1.alshallal@hotmail.com
}

\begin{abstract}
Currents study aimed at examining the impact of COVID19 on accounting profession from the perspective of accounting managers in Kuwaiti manufacturing sectors. Quantitative approach was adopted in order to gather needed data - even though researcher preferred qualitative approach but health precautions prevented that - a questionnaire was adopted and uploaded through Google forms. After application process, (177) individuals responded to the questionnaire and study indicated that COVID19 and its spread managed to increase the difficulty on accounting profession due to the decline and organizational activities and the inability to reach clear and precise data, in addition to that, study proved that what increased the burden on accounting profession that organizations didn't have the full ability to perform disclosure as according to standards and rules due to the lockdown and the continuous limiting of commercial and financial activities of organizations. Study recommended that the accounting sector must take advantage of the opportunity to learn from this experience, which needs innovation in solutions and management, to benefit from the lessons of crises.
\end{abstract}

Keywords:

COVID19, Accounting, Cloud Accounting, Assets, Recession, Financial Reports, Quality, Real Data, Disclosure, Outsourcing Article Received: 18 October 2020, Revised: 3 November 2020, Accepted: 24 December

\section{Introduction}

The Corona epidemic crisis caused a global confusion and clamor that dominated all economic sectors in all countries, and resulted in many damages that are still not clearly defined so far. After the spread of the new Corona virus pandemic around the world, no economy remained healthy around the world unless it was announced that it was negatively affected by this virus. Several days ago, the International Monetary Fund (IMF) announced that the world has entered a recession that may be worse than the recession of 2009 (Pan et al, 2020).

According to Van Fan et al (2020), in view of the great role that the accounting profession plays in the world of finance and business, it inevitably keeps pace with the changes that occur in the environment in which it operates, it is certain that it has been negatively or positively affected by this pandemic and the accompanying curfew in many countries, closing many sectors and intensifying health precautionary measures (Ahmed et al, 2020). Based on that, many researchers, scholars and specialists claimed that -
(Newbold et al, 2020), (Anderson et al, 2020), and (Sukharev, 2020) - in light of the variables of the Corona pandemic and its repercussions on all sectors and fields, it was necessary for accounting to respond to these developments in a manner appropriate and appropriate to the need for accounting analysis and disclosure to access the information provided by accounting to all users.

Aim and Objectives

Based on that, current study aimed at examining the impact of covid19 on accounting profession from the perspective of a sample of head of accounting departments within Kuwaiti sectors. Reaching such aim was possible after following a set of objectives which were:

- Identify the main aspects in which accounting was influenced

- Highlight the role of accounting profession during COVID19 pandemic

- Spot the light on the accounting approach which was followed during the pandemic lockdown and quarantine

The importance of the study stems from the problem it addresses by examining the negative or 
positive effects of the Corona pandemic on the accounting profession and accounting practices and how accountants' individuals or organizations respond to these effects by relying on new methods and standards that ensure the continuity of their work.

\section{Literature Review and Hypotheses}

Development

\subsection{The Appearance Of Covid 19}

The global Corona pandemic has dealt a painful blow to the global economy, which is already suffering from fragility, and until now, there are no explicit and clear reports capable of presenting the effects caused by Corona, not even before more time has passed (Sukharev, 2020). However, it is known that the losses caused by Corona on the world are very large and will make the areas of weakness more evident than before due to the economic and financial turmoil that the world will be exposed to later, and many financial and economic studies and analyzes have expected that the economic repercussions of the pandemic will be Corona is long-lasting and will need a lot of time for reconstruction and restoration (Leal Filho et al, 2020).

And according to Gillingham et al (2020), the main weakness in the accounting profession was a very large percentage in one stage, which is the stage of documentary examination or vouching procedures, which require the work teams at auditing, accounting and tax offices to make field visits to the client and under The current work environment that requires the application of strategies of physical distancing and the encouragement of remote work, the work of auditing, accounting and tax offices has not stopped and it has to continue to support the economic sectors professionally and technically, especially at such a time when businesses need every possible support.

While Jowitt (2020) and Sahin et al (2020) indicated that there was a role for auditing, accounting and tax offices in limiting the effects of the Coronavirus crisis, this role is considered a pivotal and important role for business, as businesses greatly need advice and technical support at such times and in Such times increase the number of risks that management must pay attention to. The risks of bankruptcy and sudden closure may loom on the horizon, and the risks of fraud are also not far away, and here comes the role of the auditor, who must play a major role in examination and review at such times to enhance confidence in The outputs of the accounts sections and so that the decision-making process is based on solid ground (WHO, 2020).

\subsection{Accounting Profession Under The Pressure}

According to Albitar et al (2020), the accounting profession has many important and complex functions, including estimating the impact of future cash flows, making adjustments to budgets, helping to manage liquidity risks, arranging priorities and adjusting contracts, assisting in the optimal investment of resources, reviewing production costs and all related logistics services, and taking into account opportunities continuity, and these jobs were greatly affected by the spread of the Corona pandemic as a result of the loss of actual communication first and the repeated closures that occurred to country sectors in general, which led to the transfer of the accounting profession to another level of jobs, the most important of which is the completion of its jobs remotely and with estimates that must be very close to reality (Papadopoulou and Papadopoulou, 2020);( Mihai et al, 2020) and (Sangster et al, 2020).

\subsection{Accounting First-Aid Strategies}

After realizing that the pandemic affected what it affected through closures, quarantines and multiple injuries, in addition to the inability to deal directly with individuals and groups, accountants and accounting and auditing offices decided to try to practice their tasks in the most adaptive way to the crisis in order to preserve rights and meet to the requests of many organizations whose financial situation has been affected by the crisis (Al-Jabali, 2020). Consequently, the accounting profession dealt with many damages by trying to employ it in one way or another to reach the result, and among the 
damages that affected the accounting profession, leading to changing its method of work, the following:

\section{Disclosure Difficulty}

The impact of the Corona pandemic on the accounting profession has varied between the mechanisms and manner of practicing the profession and the duties it must perform in these circumstances (Alhawsawi, 2020). The curfew in many countries and the many closures that the different sectors were subjected to had an impact on the organization's difficulty in providing its own disclosure due to the lack of clarity of its financial, economic and business conditions during that period (Zhu et al, 2020). However, Rinaldi et al (2020) noted that many organizations around the world have proven to be affected by the emerging corona virus pandemic, and according to international financial reporting standards, it must be disclosed if the organization has been affected by the precautionary measures and the spread of the Coronavirus.

Jinjarak et al (2020) added that the importance of disclosure during the pandemic stems from the need for the organization to disclose if there is a financial impact that has occurred from the end of the fiscal year until the publication of the financial statements to the public, and according to the $10^{\text {th }}$ standard of international standards (IAS 10), organizations are required to disclose in the financial statements clarifications about events and subsequent period of preparing the financial statements about any potential impact and risk coming due to the spread of the emerging corona virus, and disclosure is made only when there is a financial impact on the financial statements (He et al, 2020).

\section{Lack Of Clear Data}

Yu et al (2020) Indicated that among the damages caused to the accounting profession during the Corona pandemic is the loss of real and actual data as a result of closures, and therefore there was no clear evidence of numbers that could be indications of profits, losses or even sales. Kenway and Holden (2020) confirmed that as a result of the lack of clear, explicit and accurate data during the pandemic period, this had affected the quality of financial reports and thus the transmission of this effect on the foundations and standards of corporate governance as it is one of the basic elements of the economy.

This is in addition to the loss of the controls and principles in place in order to provide high-quality financial reports to stakeholders, including the board of directors, senior management and shareholders, and thus - according to Heald and Hodges (2020) - losing a large part of transparent communication about the impact of the Corona crisis on its business, in terms of liquidity and business continuity, financial position, internal control and risk.

\section{Reliance On Digital Technologies}

Regarding accounting, on the level of performance, technological progress was a decisive factor in preventing the epidemic from causing more serious harm to the way accounting and auditing functions, as the use of technology prevented work from stopping as a result of precautionary measures and lack of direct communication, so the pandemic led to the rapid expansion of the use of intelligence tools Artificial, to do accounting work (Chen et al, 2020).

It was also indicated by $\mathrm{He}$ et al (2020) that an increase in demand was observed to develop and provide these technologies and programs by organizations to meet their accounting needs with less cost and a clear saving in time and effort. Therefore, according to Lesi (2020), the accounting profession moved to computerized accounting programs and artificial intelligence for the sake of trying - as much as possible - to deal with the severe damages that many sectors have suffered, financially and economically.

\section{Decline In Economic And Financial Activity}

The Corona epidemic has had many unspecified dimensions including interruption of production, supply chain disruptions, lack of staff, decrease in sales and profits, closure of offices and warehouses, delays in planned business expansion procedures, inability to increase financing, increased volatility in The value of financial 
instruments, the decline in tourism, disruption of travel, and the cancellation of many commercial and financial activities (Elavarasan et al, 2020). Consequently, the organizations faced the risk of the necessity of stopping business and commercial activities, which led to the necessity for organizations to analyze the risks and work to recover losses resulting from the closure (Kenway and Holden, 2020). This was evidenced by the organizations demanding insurance companies to compensate for the risk of business interruption, and demanding accountants to solve the issue with unclear data and vague financial statements for numbers that could have been achieved by the organization in the event that its business was not disrupted and stopped, and this was one of the biggest challenges for the accounting profession.

\section{Outsourcing}

The use of external accounting or accounting outsourcing was the most in demand during the Corona pandemic, as many of the affected organizations indicated their need to seek the assistance of external certified accountants in preparing damage analyzes and assisting them in settling their situation (Crane and Matten, 2020). Chen et al (2020) indicated that the pandemic has proven that the accounting profession is the actual interpreter and true estimator of the results of the economic and financial crises by producing figures indicating the course of events (Mazzucato and Kattel, 2020; Andrew et al, 2020)

\section{Model and Hypotheses}

Based on previous literature review, and utilizing previous studies including Al-Jabali (2020), and Al-Qanbari (2020), researcher was able to draw the following relationship between variables:

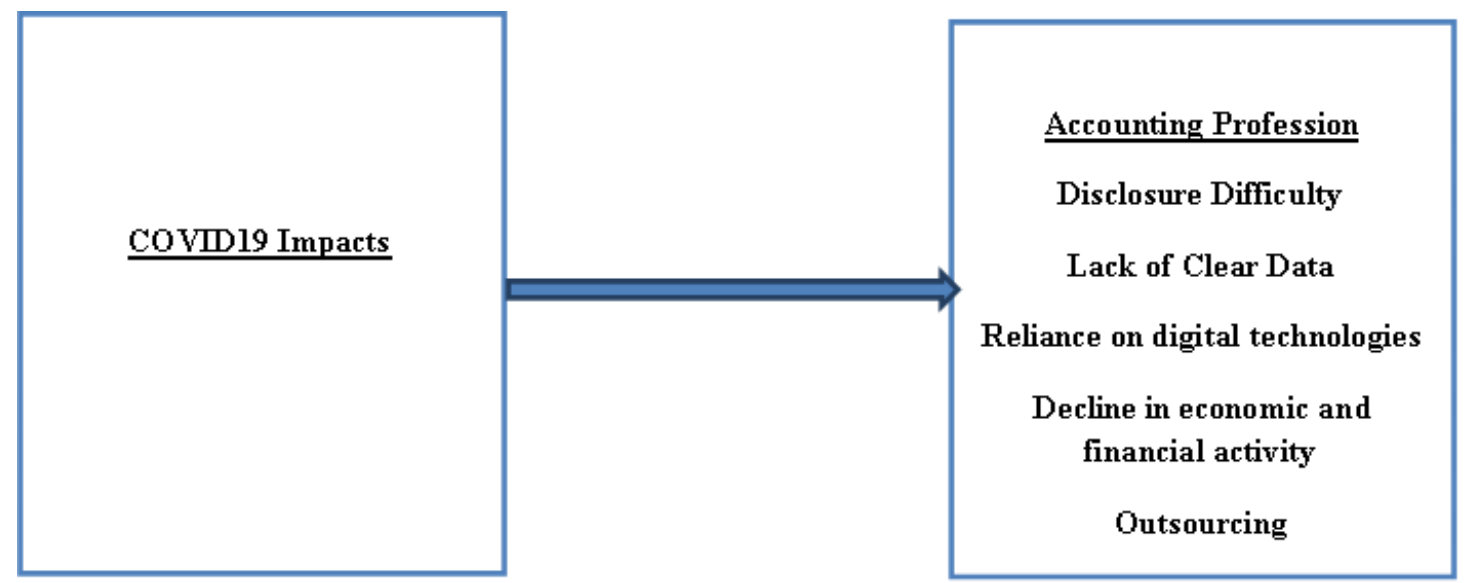

Figure - 1: Study Model Al-Jabali (2020)

From above model and depending on previous studies in forming the problem statement; following set of hypothesis was extracted:

$\mathrm{H}$ : COVID19 managed to influence accounting profession in many aspects

\section{Methods}

In order to reach main aim of study, quantitative approach was adopted through utilizing a questionnaire. The questionnaire was built on liker 5 scale (5 strongly agree, 4 agree, 3 neutral, 2 disagree, and 1 strongly disagree), in addition to that, the questionnaire consisted of two main sections, the first took into perspective demographics of respondents, while the other section took into account aspects of influence on accounting profession due to COVID19 pandemic including (Disclosure Difficulty, Lack of Clear Data, Reliance on digital technologies, Decline in economic and financial activity and Outsourcing). Population of study consisted of all accountants and auditors (external and internal) who were accessible through an online uploaded questionnaire through Kuwaiti manufacturing sector. A convenient sample of (200) individuals was chosen to represent population of study.

The questionnaire was uploaded for a time of 7 weeks in order to gather the needed data, bearing in mind that COVID19 health precautions 
prevented the actual distribution of questionnaire. After application process researcher was able to retrieve (177) properly filled questionnaires, which indicated a response ratio of $(88.5 \%)$ as statistically accepted.

SPSS was utilized in order to tackle, screen and analyze gathered data; Cronbach's Alpha was used in order to test the reliability of study tool, the test resulted in a value of (0.948) for all the items within the study, the alpha however resulted greater than 0.60 which indicated the tool consistency that enhanced its use in the study.

\section{Analysis and Discussion}

\subsection{Demographics}

Looking at table 1, demographics of respondents were calculated by referring to frequency and percentage. Results indicated that majority of sample who responded to questionnaire was (male) forming (68.4\%) of study, as for age range, it appeared that majority of head of accounting departments' age ranged between (31-37) forming (42.4\%) of total sample. Educational qualification appeared for the benefit of those who held (BA) degree forming $(49.7 \%)$ of sample and who had an experience of $(+14)$ years forming $(35 \%)$ of total sample.

Table - 1: Analysis of Sample Demographics

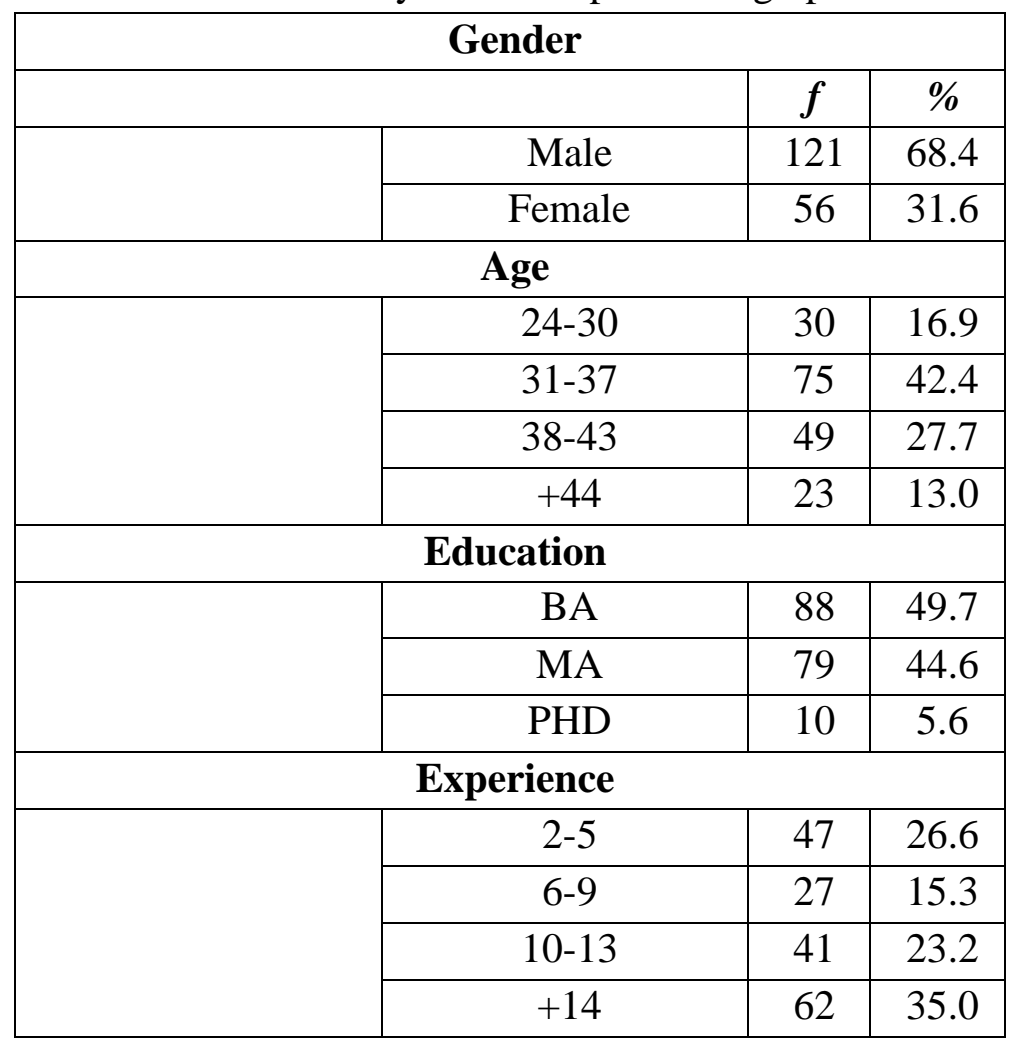

\subsection{Questionnaire Analysis}

In the following table 2, statements of questionnaire were calculated in terms of mean and standard deviation. It appeared that respondents had positive attitudes towards statements of questionnaire given that all statements recorded higher than mean of scale 3.00 which was statistically positive. The most positively answered statements stemmed from the variable of (disclosure difficulty) articulated "Difficulty disclosing if the company has been affected by the precautionary measures spreading the Coronavirus" and scored a mean of (3.50) compared to the least positively answered statement which stemmed from (lack of clear data) articulated "Difficulty dealing with financial statements due to the impact of the value of the company's assets" and scored a mean of (3.18). 
Table - 2: Questionnaire Mean and standard Deviation

\begin{tabular}{|c|c|c|}
\hline & Mean & $\begin{array}{c}\text { Std. } \\
\text { Deviation }\end{array}$ \\
\hline \multicolumn{3}{|l|}{ Disclosure Difficulty } \\
\hline $\begin{array}{l}\text { 1. Difficulty disclosing if the company has been affected by the } \\
\text { precautionary measures spreading the Coronavirus. }\end{array}$ & 3.50 & 1.407 \\
\hline $\begin{array}{l}\text { 2. The companies disclose the potential risks and no amendment } \\
\text { is made to the body of the financial statements }\end{array}$ & 3.46 & 1.306 \\
\hline $\begin{array}{l}\text { 3. The pandemic has forced organizations to change the way } \\
\text { financial statements are presented, and this requires a } \\
\text { fundamental change in the accounting basis. }\end{array}$ & 3.40 & 1.197 \\
\hline 4. Debt repayment dates differ, and there is no clear financial data & 3.46 & 1.201 \\
\hline $\begin{array}{l}\text { 5. Volatility in financial market prices and the depreciation of } \\
\text { some investments. }\end{array}$ & 3.43 & 1.137 \\
\hline \multicolumn{3}{|l|}{ Lack of Clear Data } \\
\hline $\begin{array}{l}\text { 6. The need for conducting research and studies emerged to } \\
\text { suggest solutions for accounting for the effects of the pandemic }\end{array}$ & 3.27 & 1.189 \\
\hline $\begin{array}{c}\text { 7. Strong and efficient financial and accounting oversight bodies } \\
\text { are becoming more important and more valuable }\end{array}$ & 3.19 & .975 \\
\hline $\begin{array}{l}\text { 8. Difficulty dealing with financial statements due to the impact } \\
\text { of the value of the company's assets. }\end{array}$ & 3.18 & .922 \\
\hline $\begin{array}{l}\text { 9. Delinquency of the debtor in paying the amounts due and thus } \\
\text { a re-evaluation of the ECL risk model }\end{array}$ & 3.29 & .956 \\
\hline 10. Lack of clear asset valuation data & 3.45 & .965 \\
\hline \multicolumn{3}{|l|}{ Reliance on Digital Technology } \\
\hline $\begin{array}{l}\text { 11. Technology accounting applications have been a critical factor } \\
\text { in preventing the pandemic from causing harm to accounting } \\
\text { jobs }\end{array}$ & 3.33 & 1.009 \\
\hline $\begin{array}{l}\text { 12. The use of technology prevented work from stopping due to } \\
\text { precautionary measures and lack of direct communication }\end{array}$ & 3.36 & 1.025 \\
\hline $\begin{array}{l}\text { 13. The pandemic has led to a rapid expansion in the use of } \\
\text { artificial intelligence tools to do accounting work }\end{array}$ & 3.38 & .971 \\
\hline $\begin{array}{l}\text { 14. The pandemic has increased the demand for companies to } \\
\text { develop and introduce accounting technologies and programs }\end{array}$ & 3.20 & 1.160 \\
\hline $\begin{array}{l}\text { 15. Software based on artificial intelligence is becoming more and } \\
\text { more used in the accounting profession }\end{array}$ & 3.20 & 1.192 \\
\hline \multicolumn{3}{|l|}{ Decline in Economic and Financial Activity } \\
\hline $\begin{array}{l}\text { 16. The pandemic has made it difficult to estimate the extent to } \\
\text { which future cash flows will be affected }\end{array}$ & 3.55 & 1.133 \\
\hline $\begin{array}{l}\text { 17. Organizations have had to make adjustments to budgets and } \\
\text { help manage liquidity risks }\end{array}$ & 3.47 & 1.066 \\
\hline $\begin{array}{l}\text { 18. The pandemic caused the value of inventory to fall below the } \\
\text { cost of purchasing it }\end{array}$ & 3.40 & 1.094 \\
\hline $\begin{array}{l}\text { 19. Lockdown and quarantine decreased the purchase power of } \\
\text { non-essential needs which decreased profit compared to cost }\end{array}$ & 3.38 & 1.016 \\
\hline
\end{tabular}




\begin{tabular}{|l|c|c|}
\hline \multicolumn{3}{|c|}{ Outsourcing } \\
\hline $\begin{array}{l}\text { 20. } \begin{array}{l}\text { The affected organizations outsourced accountants to prepare } \\
\text { damage analyzes and assist them in regularizing their situation }\end{array} \\
\begin{array}{l}\text { 21. During the pandemic, accounting became the real interpreter } \\
\text { and true estimator of the consequences of the economic and } \\
\text { financial crises }\end{array}\end{array}$ & 3.60 & .937 \\
\hline $\begin{array}{l}\text { 22. Depending on outsourcing helped in increasing level of } \\
\text { confusion among stakeholders }\end{array}$ & 3.30 & 1.170 \\
\hline $\begin{array}{l}\text { 23. Organizations had to reduce payroll costs while adding highly } \\
\text { qualified experts with a deep pool of resources }\end{array}$ & 3.36 & .937 \\
\hline 24. Outsourcing appeared the best choice during covid19 & 3.33 & 1.194 \\
\hline
\end{tabular}

\subsection{Descriptive Statistics}

Total 3 presented means of questionnaire statements were calculated as according to variables adopted in study. It appeared that (Decline in economic and financial activity) was the most positively answered variable scoring a mean of (3.45) compared to (Lack of Clear Data) as the least positively answered variables scoring a mean of (3.27). Generally speaking, below table showed that all variables scored high means that are above mean of scale which was indicated as a positive attitude from respondents.

Table 3. Descriptive Statistics of Variables

\begin{tabular}{|c|c|c|}
\hline & Mean & Std. Deviation \\
\hline Disclosure Difficulty & 3.4497 & 1.06099 \\
\hline Lack of Clear Data & $\underline{\mathbf{3 . 2 7 6 8}}$ & .84179 \\
\hline Reliance on digital technologies & 3.2960 & .90179 \\
\hline Decline in economic and financial activity & $\underline{\mathbf{3 . 4 5 0 6}}$ & .94261 \\
\hline Outsourcing & 3.3842 & .83160 \\
\hline TOTAL & 3.3682 & .73827 \\
\hline
\end{tabular}

\subsection{Hypotheses Testing}

\section{H: COVID19 has an impact on accounting profession}

Table 4. Testing Main Hypothesis

\begin{tabular}{|c|c|c|c|}
\hline \multicolumn{4}{|c|}{ One-Sample Statistics } \\
\hline & Mean & Std. Deviation & Std. Error Mean \\
\hline TOTAL & 3.3682 & .73827 & .05549 \\
\hline Disclosure Difficulty & 3.4497 & 1.06099 & .07975 \\
\hline Lack of Clear Data & 3.2768 & .84179 & .06327 \\
\hline Reliance on digital technologies & 3.2960 & .90179 & .06778 \\
\hline Decline in economic and financial activity & 3.4506 & .94261 & .07085 \\
\hline Outsourcing & 3.3842 & .83160 & .06251 \\
\hline
\end{tabular}

Table 5. One-Sample Test

\begin{tabular}{|c|c|c|c|c|c|c|}
\hline & \multicolumn{6}{|c|}{ Test Value $=3$} \\
\hline & \multirow[b]{2}{*}{$\mathrm{t}$} & \multirow[b]{2}{*}{ df } & \multirow[b]{2}{*}{ Sig. (2-tailed) } & \multirow[b]{2}{*}{ Mean Difference } & \multicolumn{2}{|c|}{$\begin{array}{l}\text { 95\% Confidence Interval of the } \\
\text { Difference }\end{array}$} \\
\hline & & & & & Lower & Upper \\
\hline TOTAL & 6.635 & 176 & .000 & .36817 & .2587 & .4777 \\
\hline
\end{tabular}




\begin{tabular}{|c|c|c|c|c|c|c|}
\hline $\begin{array}{c}\text { Disclosure } \\
\text { Difficulty }\end{array}$ & 5.639 & 176 & .000 & .44972 & .2923 & .6071 \\
\hline Lack of Clear Data & 4.375 & 176 & .000 & .27684 & .1520 & .4017 \\
\hline $\begin{array}{c}\text { Reliance on digital } \\
\text { technologies }\end{array}$ & 4.368 & 176 & .000 & .29605 & .1623 & .4298 \\
\hline $\begin{array}{c}\text { Decline in } \\
\text { economic and } \\
\text { financial activity }\end{array}$ & 6.359 & 176 & .000 & .45056 & .3107 & .5904 \\
\hline Outsourcing & 6.146 & 176 & .000 & .38418 & .2608 & .5075 \\
\hline
\end{tabular}

One sample t test is used to test above hypothesis, it is found that $\mathrm{t}$ value $=6.635$ is significant at 0.05 level that means, COVID19 has an impact on accounting profession.

Above hypothesis was divided in to following sub hypothesis:

\section{H1: COVID19 has an impact on Disclosure Difficulty}

One sample $t$ test is used to test above hypothesis, it is found that $\mathrm{t}$ value $=5.639$ is significant at 0.05 level that means, COVID19 has an impact on Disclosure Difficulty.

H2: COVID19 has an impact on Lack of Clear

\section{Data}

One sample $t$ test is used to test above hypothesis, it is found that $\mathrm{t}$ value $=4.375$ is significant at 0.05 level that means, COVID19 has an impact on Lack of Clear Data.

\section{H3: COVID19 has an impact on Reliance on digital technologies}

One sample t test is used to test above hypothesis, it is found that $\mathrm{t}$ value $=4.368$ is significant at 0.05 level that means, COVID19 has an impact on Reliance on digital technologies.

H4: COVID19 has an impact on Reliance on Decline in economic and financial activity

One sample t test is used to test above hypothesis, it is found that $\mathrm{t}$ value $=6.359$ is significant at 0.05 level that means, COVID19 has an impact on Reliance on Decline in economic and financial activity.

\section{H5: Covid19 Has An Impact On Reliance On Outsourcing}

One sample $t$ test is used to test above hypothesis, it is found that $\mathrm{t}$ value $=6.146$ is significant at 0.05 level that means, COVID19 has an impact on Reliance on Outsourcing
Discussion

Currents study aimed at examining the impact of COVID19 on accounting profession from the perspective of accounting managers in Kuwaiti sectors. Quantitative approach was adopted in order to gather needed data - even though researcher preferred qualitative approach but health precautions prevented that - a questionnaire was adopted and uploaded through Google forms. After application process, (177) accountants and auditors responded to the questionnaire and the following results appeared:

- Responded seemed to have high awareness of COVID19 impact on accounting profession as they were able to answer all questionnaire freely

- COVID 19 appeared to have an influence on accounting profession as it scored a high significance of 6.635

- Among the most apparent difficulties that face accountants during the spread of COVID19 appeared to be the decline in economic and financial activity scoring a significance of 6.35

- The least influential variable appeared to be the reliance on digital technologies scoring a significance of 4.36

The study showed that the accounting profession was affected during the Corona pandemic in terms of disclosure, given that organizations are content to disclose potential risks, and the amendment is not made to the core of the financial statements except in the event that there is an impact on the continuity of the organization, in this case the organization must change the way the financial statements are presented and this matter requires a fundamental change in the accounting basis, which is a solution based on a lot of challenge. 
Such results agreed with Alhawsawi (2020), Rinaldi et al (2020), Zhu et al (2020), Jinjarak et al (2020) and He et al (2020).

In terms of the highest variable in influence which is the lack of clear data; study also proved that the loss of actual and real data contributed to affecting the outputs of the accounting profession, as the impact of this pandemic extended on the financial statements of many organizations, starting from the first quarter of 2020, this effect reached a change in the organization's revenues, which led to the negative impact of the organization's assets value. In addition, the study found that the stock is one of the non-financial assets of the organization, which has been subjected to a decrease in value due to the decrease and stagnation of sales and consequently the decrease in the value of the stock below the cost of its purchase, which is called the net recoverable value of the stock according to international accounting standard (IAS 2).

This agreed with what $\mathrm{Yu}$ et al (2020), Kenway and Holden (2020) and Heald and Hodges (2020) noted that the impact of the pandemic on the accounting profession is represented by the lack of data for organizations due to the lack of clear data to evaluate assets, for example, especially since there are some organizations that have assets abroad and the account auditors have not been provided with the evaluation of these assets, which is what prompts the auditor in this case to be reserving the financial statements and expressing his opinion through the financial reports. Thus, the result is a reservation on the financial statements issued by the organizations in the absence of the information necessary to evaluate the assets of those organizations.

Depending on IT and computerized programs appeared as the least influential factors, however, the study indicated that digital platforms were among the mechanisms that were adopted in order to complete accounting functions during the crisis, and this matter had a positive effect in controlling the damage as much as possible, as it is due to closures and difficulty of actual communication, accountants were supposed to maintain the highest level of transparency, control and disclosure of financial statements by ensuring that the financial statements have the ability to express the financial position of the organizations.

Results of study also matched what was indicated by $\mathrm{He}$ et al (2020) when they argued that the accounting profession with all its functions contributed greatly to the success of some business sectors during the pandemic period by preparing scenarios to confront the virus - from an accounting perspective - and limit its growing repercussions. From here, Chen et al (2020) and Lesi (2020) also indicated that successful computerized AIS were able to meet the needs of the decision-making process related to the crisis in an appropriate and timely manner, which contributed to maximizing the capabilities and capabilities of crisis management and limiting its negative effects.

\section{Conclusion and Recommendations}

The effects of the Corona epidemic on the accounting profession were significant and noticeable through the difference in the mechanism and methods of dealing with accounting data and the basis that is adopted when preparing financial statements and reports. However, as it was noted through the current study and previous studies that the role of the accounting profession did not depend on the time of the crisis only, but will extend until after its end, because organizations will need to conduct research and studies to propose accounting solutions to the effects of the pandemic, so there is a great work awaiting accountants after the pandemic receded to address its implications.

Accordingly, the strong and efficient financial and accounting oversight bodies are becoming more and more important and their value rises now and in the future, as they will play a major role in auditing programs and expenditures, and in helping to develop plans for how to prepare and deal with such epidemics and crises in the future. Study presented a practical implication which indicated that Corona crisis will change the way accounting profession is taught in the post-crisis phase, as digital technologies will change the 
method and mechanisms of teaching accounting by practitioners.

Based on previous results, discussion and conclusion; current study recommended the following:

- The accounting sector must take advantage of the opportunity to learn from this experience, which needs innovation in solutions and management, to benefit from the lessons of crises.

- Organizations need to take appropriate steps to enhance risk management in order to prevent mishandling of similar crises in the future.

\section{References}

[1] Ahmed, D., Buheji, M., \& Fardan, S. (2020). Re-emphasising the future family role in "care economy" as a result of covid-19 pandemic spillovers. American Journal of Economics, 10(6), 332-338.

[2] Albitar, K., Gerged, A. M., Kikhia, H., \& Hussainey, K. (2020). Auditing in times of social distancing: the effect of COVID-19 on auditing quality. International Journal of Accounting \& Information Management.

[3] Alhawsawi, M. (2020). Soft Accounting Skills between Employers' Expectations and Students' Reality after COVID-19 Pandemic. Australian Academy of Accounting and Finance Review, 5(2), 69-76.

[4] Al-Jabali, W. (2020). The impact of the spread of the Corona pandemic on preparing and reviewing financial statements: A Field Study, Scientific Journal of Accounting Research, 2(1)

[5] Al-Qanbari, M. (2020). The effects of the Corona epidemic on accounting business, Encyclopedia of Islamic Economics and Finance, 1(4)

[6] Anderson, R. M., Heesterbeek, H., Klinkenberg, D., \& Hollingsworth, T. D. (2020). How will country-based mitigation measures influence the course of the COVID19 epidemic?. The Lancet, 395(10228), 931934.

[7] Andrew, J., Baker, M., Guthrie, J., \& MartinSardesai, A. (2020). Australia's COVID-19 public budgeting response: the straitjacket of neoliberalism. Journal of Public Budgeting, Accounting \& Financial Management.

[8] Chen, G., Cheng, M., Edwards, D., \& Xu, L. (2020). COVID-19 pandemic exposes the vulnerability of the sharing economy: a novel accounting framework. Journal of Sustainable Tourism, 1-18.

[9] Crane, A., \& Matten, D. (2020). COVID-19 and the future of CSR research. Journal of Management Studies.

[10] Elavarasan, R. M., Shafiullah, G. M., Raju, K., Mudgal, V., Arif, M. T., Jamal, T., ... \& Subramaniam, U. (2020). COVID-19: Impact analysis and recommendations for power sector operation. Applied energy, 279, 115739.

[11] Gillingham, K. T., Knittel, C. R., Li, J., Ovaere, M., \& Reguant, M. (2020). The Short-run and Long-run Effects of Covid-19 on Energy and the Environment. Joule, 4(7), 1337-1341.

[12] He, P., Niu, H., Sun, Z., \& Li, T. (2020). Accounting index of COVID-19 impact on Chinese industries: A case study using big data portrait analysis. Emerging Markets Finance and Trade, 56(10), 2332-2349.

[13] Heald, D., \& Hodges, R. (2020). The accounting, budgeting and fiscal impact of COVID-19 on the United Kingdom. Journal of Public Budgeting, Accounting \& Financial Management, 32(5), 785-795

[14] Jinjarak, Y., Ahmed, R., Nair-Desai, S., Xin, W., \& Aizenman, J. (2020). Accounting for Global COVID-19 Diffusion Patterns, January-April 2020 (No. w27185). National Bureau of Economic Research.

[15] Jowitt, S. M. (2020). COVID-19 and the Global Mining Industry. SEG Discovery, (122), 33-41.

[16] Kenway, P., \& Holden, J. (2020). Accounting for the Variation in the Confirmed Covid-19 Caseload across England: An analysis of the role of multi-generation households, London and time. New Policy Institute, London. 
[17] Leal Filho, W., Brandli, L. L., Lange Salvia, A., Rayman-Bacchus, L., \& Platje, J. (2020). COVID-19 and the UN sustainable development goals: threat to solidarity or an opportunity?. Sustainability, 12(13), 5343.

[18] Lesi, H. (2020). The Influence of Information Technology Covid-19 Plague Against Financial Statements and Business Practices. Ilomata International Journal of Tax and Accounting, 1(3), 122-131.

[19] Mazzucato, M., \& Kattel, R. (2020). COVID19 and public-sector capacity. Oxford Review of Economic Policy, 36(Supplement_1), S256-S269.

[20] Mihai, F., Stan, M., Radu, G., \& Dumitru, V. F. (2020). Heavy Work Investment for the Accounting Profession in Romania at Time of Coronavirus Pandemic. Amfiteatru Economic, 22(14), 1121-1139.

[21] Newbold, S. C., Finnoff, D., Thunström, L., Ashworth, M., \& Shogren, J. F. (2020). Effects of physical distancing to control COVID-19 on public health, the economy, and the environment. Environmental and Resource Economics, 76(4), 705-729.

[22] Pan, D., Yang, J., Zhou, G., \& Kong, F. (2020). The influence of COVID-19 on agricultural economy and emergency mitigation measures in China: A text mining analysis. PloS one, 15(10), e0241167.

[23] Papadopoulou, S., \& Papadopoulou, M. (2020). The Accounting Profession Amidst the COVID-19 Pandemic. International Journal of Accounting and Financial Reporting, 10(2.39-59).

[24] Rinaldi, L., Cho, C. H., Lodhia, S. K., Michelon, G., \& Tilt, C. A. (2020, July). Accounting in times of the COVID-19 pandemic: a forum for academic research. In Accounting Forum (Vol. 44, No. 3, pp. 180-183). Routledge.

[25] Sahin, O., Salim, H., Suprun, E., Richards, R., MacAskill, S., Heilgeist, S., ... \& Beal, C.
D. (2020). Developing a preliminary causal loop diagram for understanding the wicked complexity of the COVID-19 pandemic. Systems, 8(2), 20.

[26] Sangster, A., Stoner, G., \& Flood, B. (2020). Insights into accounting education in a COVID-19 world. Accounting Education, 29(5), 431-562.

[27] Sukharev, O. S. (2020). Economic crisis as a consequence COVID-19 virus attack: risk and damage assessment. Quantitative Finance and Economics, 4(2), 274-293.

[28] Van Fan, Y., Jiang, P., Hemzal, M., \& Klemeš, J. J. (2020). An update of COVID19 influence on waste management. Science of the Total Environment, 754, 142014.

[29] World Health Organization. (2020). COVID19 global risk communication and community engagement strategy, December 2020-May 2021: interim guidance, 23 December 2020 (No. WHO/2019nCoV/RCCE/2020.3). World Health Organization.

[30] Yu, A. (2020). Accountability as mourning: Accounting for death in the time of COVID19. Accounting, Organizations and Society, 101198.

[31] Zhu, J., Qiu, W., \& Jian, W. (2020, October). Evaluating Impacts of the COVID-19 Pandemic on China's Container Ports Based on AIS Big Data. In Journal of Physics: Conference Series (Vol. 1624, No. 3, p. 032050). IOP Publishing. 